\title{
Structure of the Kasbah fold zone (Agadir bay, Morocco). Implications on the chronology of the recent tectonics of the western High Atlas and on the seismic hazard of the Agadir area
}

\author{
Estructura de la zona de plegamiento de Kasbah (Bahía de Agadir, \\ Marruecos). Implicaciones en la cronología de la tectónica reciente \\ del Alto Atlas occidental y la peligrosidad sísmica del área de Agadir
}

\author{
A. Mridekh' ${ }^{1}$, F. Medina ${ }^{2}$, N. Mhammdi², F. Samaka ${ }^{3}$, R. Bouatmani ${ }^{4}$
}

\begin{abstract}
Detailed re-interpretation of the north-eastern segment of a profile realized across the Agadir bay along a NE-SW trend and crosscutting the main structures, together with analysis of available isochron maps, allowed us to retrace the geological history of the offshore western High Atlas. Two tectonostratigraphic sequences were distinguished: Unit II, which displays a simple structure, laying unconformably on Unit I, with a more complex structure dominated by a reverse fault (F1) striking E-W with a dip to the north. Correlation to boreholes Souss-1 and AGM-1 allowed us to assign Unit I to the Triassic - Palaeogene and Unit II to the Miocene - Present. The NE fault block shows a ramp-flat fault plane (F2) with an overlying SW-vergent fold that can be interpreted as a fault-bend fold. Three main stages were distinguished: (1) during the Cretaceous, F1 could have been a syndepositional normal fault with the NE block moving downwards; (2) towards the beginning of the Tertiary, the displacement of plane F2 induced the development of a fault-bend fold and erosion of the forelimb and hinge of the fold; displacement along F2 was transferred to fault F1; (3) afterwards, during the Miocene, reverse motion of F1 deformed and tilted the plane F2 and accentuated the folded structure. This evolution is typical for a frontal basin above a fault-related fold. Evaluation of the thickness and bed depth differences shows that the largest growth rate was recorded in Late Miocene times. Seismic activity recorded in the Agadir bay appears to be clearly related to this fault zone, as inferred from focal mechanisms. Seismic moment evaluation suggests that earthquakes of magnitude $\mathrm{Mw} \geq 6$ are likely to occur, but could not be much larger because of the fault segmentation geometry of the High Atlas Front.
\end{abstract}

Key words: Morocco, Agadir bay, High Atlas, Atlantic margin, petroleum exploration, compressional tectonics, seismic hazard.

\section{RESUMEN}

A partir de una detallada reinterpretación del segmento nororiental de un perfil que corta las principales estructuras de la bahía de Agadir a lo largo de una directriz NE-SW, y un análisis de los mapas de isocronas disponibles, se ha podido establecer la historia geológica de la costa del Alto Atlas occidental.

En primer lugar, se han distinguido dos secuencias tectonoestratigráficas: la Unidad II, que muestra una estructura simple, y la Unidad I, de estructura más compleja dominada por una falla inversa (F1) de dirección E-W vergente al norte, sobre la que se dispone la Unidad II de forma discordante. La correlación con los sondeos Souss-1 y AGM-1 ha permitido asignar la Unidad I al Triásico-Paleógeno y la Unidad II al Mioceno-Presente. El bloque NE de la falla muestra un plano de falla de tipo rampa-rellano (F2) con un pliegue superpuesto vergente al SW que puede ser interpretado como un pliegue de flexión

\footnotetext{
1 Université Moulay Ismail, Faculté des Sciences et Techniques, Département de Géologie, Errachidia, Morocco.

2 Université Mohammed V - Agdal, Institut Scientifique, Département des Sciences de la Terre, B.P. 703 Agdal, Rabat, Morocco. e-mail: medina@israbat.ac.ma

3 ONHYM, pole Hydrocarbures, Av. Al Fadila, CYM, Rabat. Present address: Institut privé La Réserve, Mehdia (Kenitra), Morocco

${ }^{4}$ GETECH Group plc, Elmete Hall, Elmet lane, Leeds LS8 2LJ, United Kingdom.
} 
de falla. Respecto a su evolución temporal, se han distinguido tres estadios: 1) Durante el Cretácico, F1 pudo haber sido una falla normal sindeposicional, con el bloque NE desplazándose hacia abajo; 2) Al comienzo del Terciario, el desplazamiento del plano F2 indujo el desarrollo de un pliegue de flexión de falla y la posterior erosión de su flanco anterior y de la charnela (el desplazamiento a lo largo de F2 fue transferido a F1); y 3) Durante el Mioceno el desplazamiento inverso de F1 deformó y basculó el plano F2, acentuando la estructura de plegamiento. Esta evolución es típica de una cuenca frontal situada sobre un plegamiento relacionado con fallas. La evaluación del espesor y las diferencias de profundidad del lecho muestra que la mayor tasa de crecimiento se registró durante el Mioceno tardío.

La actividad sísmica registrada en la Bahía de Agadir parece estar claramente relacionada con esta zona de fracturación, como se infiere de los mecanismos focales. La evaluación del momento sísmico sugiere que los terremotos de magnitud $\mathrm{Mw} \geq 6$ son probables, pero no mayores, debido a la geometría segmentada de la fracturación del frente del Alto Atlas.

Palabras clave: Marruecos, Bahía de Agadir, Alto Atlas, Margen atlántico, exploración petrolera, tectónica compresiva, peligrosidad sísmica.

\section{Introduction}

In the Moroccan High Atlas, the southernmost Alpine chain of the western Mediterranean, the major uplift phase was recorded in Late Miocene Pliocene times, as can be inferred from the thick conglomerate formations deposited at the chain borders, which contain clasts derived from the uplifted relief (Duffaud, 1981, Petit et al., 1985, Medina, 1986, 1994, Fraissinet et al., 1988, Zouine, 1993, Chellaï \& Perriaux, 1996, Aït Hssaine, 2000). In the western High Atlas (fig. 1), which represents the Atlantic termination of the Atlas chain (e.g. Hafid et $a l ., 2000)$, the Palaeogene and pre-Moghrebian (Pliocene) Neogene cover near Agadir was in great part eroded, except in a few locations, where the Maastrichtian beds are overlain by the Early Miocene "White Conglomerate" (Conglomérat blanc), the probable Messinian, and the Pliocene / Moghrebian formations (Allard et al., 1958; Duffaud, 1962; Ambroggi, 1963; Weisrock, 1980; Alonso-Gavilán et al., 2001). In the marine part, boreholes and seismic-reflection profiles performed since the latest 1970's (Flament-Lieffrig, 1979), and in particular during the last decade (Mridekh et al., 2000; Samaka, 2001; Mridekh, 2002; Hafid et al., 2006), have provided valuable information on the Cenozoic strata, because of their better preservation, frequently with a large thickness. The numerous structures mapped (fig. 1) are related to halokinesis and syndepositional tectonics, mainly in a compressional setting.

One of the most conspicuous structures in the area is the Kasba Fold Zone (zone des plis de la Kasba; Mridekh et al., 2000; Mridekh, 2002; hereafter abbreviated to KFZ), also called the "Elkasba monocline" (flexure d'Elkasba) by Hafid et al. (2006), which is the northernmost offshore struc- ture of the Agadir bay. Interpretation of the structures related to this fold zone suggests that, contrary to the emerged part of the western High Atlas, deformation seems to have been continuous in Tertiary times.

In this paper, we expose new details on the geometry and chronology of the KFZ frontal fault, based on the re-interpretation of a selected seismic profile segment, and referring to fold kinematic constraints (e.g. Suppe, 1983; Suppe \& Medwedeff, 1990; Wickham, 1995). These new observations are also useful for updating the chronology of the Atlasic compressional events in the area, and assessing the seismic hazard of the Agadir city, which has already been destroyed on February, 29 ${ }^{\text {th }}, 1960$, by a large earthquake $\left(I_{M S K}=\mathrm{X} ; M=6\right)$, with a death toll of about 12,000 (see review in Cherkaoui et al., 1991).

\section{Structural setting}

The studied profile (hereafter referred to as "Profile A"), trending NE-SW, is located in the Agadir bay, west of the city (fig. 1). The formations in the bay are crosscut by a major, NE-SW striking vertical fault, called the "Marine" Tildi fault-corridor (couloir de failles du Tildi; Mridekh, 2002), reaching $30 \mathrm{~km}$ in length (fig. 1, TD). This fault separates two structurally-contrasting blocks (Mather, 1980, Samaka, 2001, Mridekh, 2002):

- The south-eastern block shows a simple structure; isochron curves of the main units suggest a steady dip to the NW, in continuity with the southern limb of the Souss asymmetric syncline, the axis of which, trending ENE-WSW, is located south of Agadir (Mustaphi et al., 1997).

- The more complex north-western block is folded, faulted and crosscut by diapir structures. 


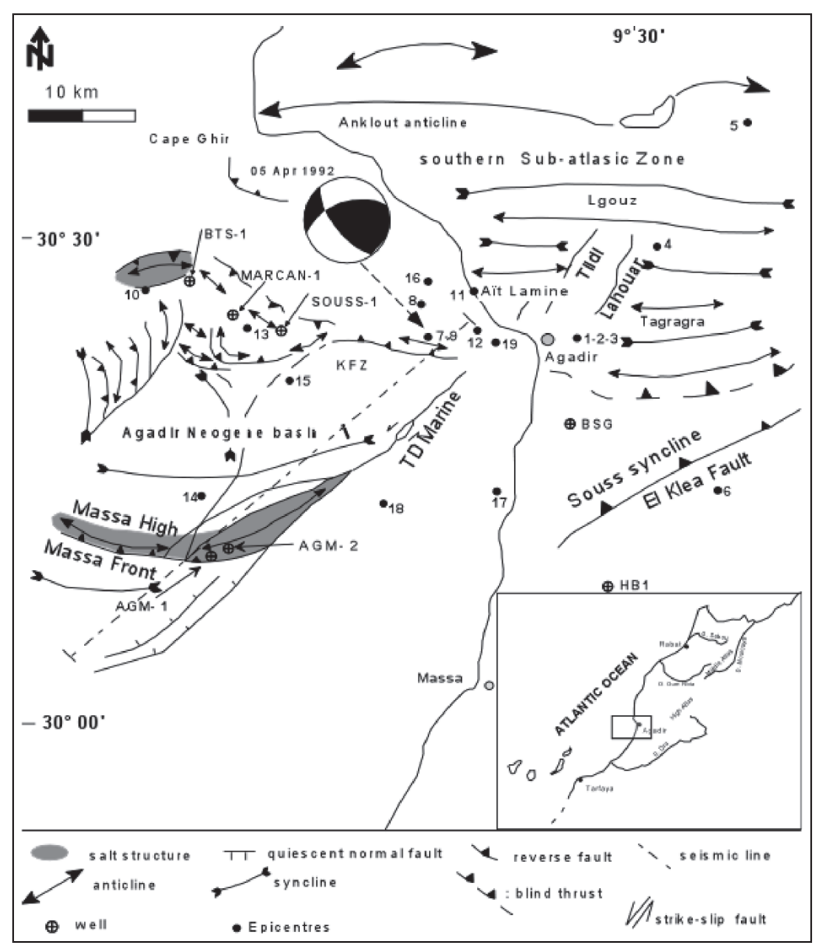

Fig. 1.-Map of recognized structures in the Agadir bay (modified from Mridekh 2000), location of the studied profile (dashed line), and epicentres of earthquakes $\left(9.5^{\circ}-10.05^{\circ} \mathrm{W} ; 30.25^{\circ}-30.7^{\circ} \mathrm{N}\right)$ for the period 1960-2007, and focal mechanism of the 1992, April, $5^{\text {th }}$ earthquake (after El Alami et al., 1992).

Isochrons of the top of the Albian, striking NW-SE near the coastal area, rapidly deepen to the southwest, reaching 2.5 sTWT (Mather, 1980, Samaka, 2001). The same can be observed for the top of the Turonian (Mridekh, 2002).

On the map and on the regional profile (figs 1 and 2), the most important structures are, according to the nomenclature of Mridekh et al. (2000), and Mridekh (2002):

- The Kasba fold zone (KFZ), a structural high oriented E-W to WNW-ESE, located in continuity with the southwestern closure of the Ait Lamine anticline (Duffaud, 1962).

- The Agadir and Massa basins, which are synclinal depressions filled with Neogene to Quaternary, and minor Palaeocene deposits. These basins are separated from each other by the E-W trending Massa Front.

- The Massa Front, trending mainly E-W, becoming WNW-ESE to the west. This structure corresponds to an anticline developed upon a blind thrust (Hafid et al., 2006), which can be interpreted as a fault-propagation fold, with a probable inter- ference of salt (Mridekh et al., 2000). Genetically, the development of this fold in a corner may also be related to left-lateral strike-slip motion of the Tildi Marine fault.

All these structures appear west of the trace of the Tildi marine fault, which is injected with a Triassic salt wall partly within a releasing stepover. The much larger amount of shortening in the northwestern block indicates a sinistral strike-slip motion, clearly transferring the front of the High Atlas to the southwest.

Inland, the general structure is that of a ENEWSW asymmetric syncline, the "Souss syncline", bounded to the north by the highly segmented southern sub-atlasic zone ("zone sub-atlasique méridionale"; Duffaud, 1962; Ambroggi, 1963), with ENE-WSW to WNW-ESE folds (Lgouz, Tagragra and Ait Lamine), offset by the NE-SW tear faults of oued Tildi and oued Lahouar (Duffaud, 1962), and by the recently suggested N-S Ameskroud Fault (Sébrier et al., 2006). These structures merge with a deep detachment fault (Mustaphi et al., 1997) which is accommodated in the foreland within the Souss syncline, against the El Klea fault (El Maamar, 1988; Mustaphi, 1997; Mustaphi et al., 1997; fig. 1).

\section{Stratigraphy and seismostratigraphy}

\section{Borehole data}

Among several boreholes performed in the Agadir bay, the nearest to the studied profile are AGM-1, Souss-1 (fig. 1) and MARCAN-1.

The Souss-1 borehole (fig. 3) was used for tying the seismic units, with the exception of the shallowest units of the Agadir offshore basin, which wedge out towards the borehole.

The following units were penetrated, from top to base (in Mridekh, 2002):

- $45 \mathrm{~m}$ of Pliocene deposits.

- Fine sandstones (45-347.5), which yielded in their upper part Globorotalia cf. plesiotumida Blow and G. merotumida Blow of Upper Miocene age.

- Yellowish to grey shales, with interbedded fine sandstones (347.5-850), assigned to the Middle Miocene.

- Soft shales with silt intercalations (850-1,376 m) dated as Lower Miocene.

- Shales and sands $(1,376-1,723)$ assigned to the Oligocene and to the Eocene; this dating is 
NE
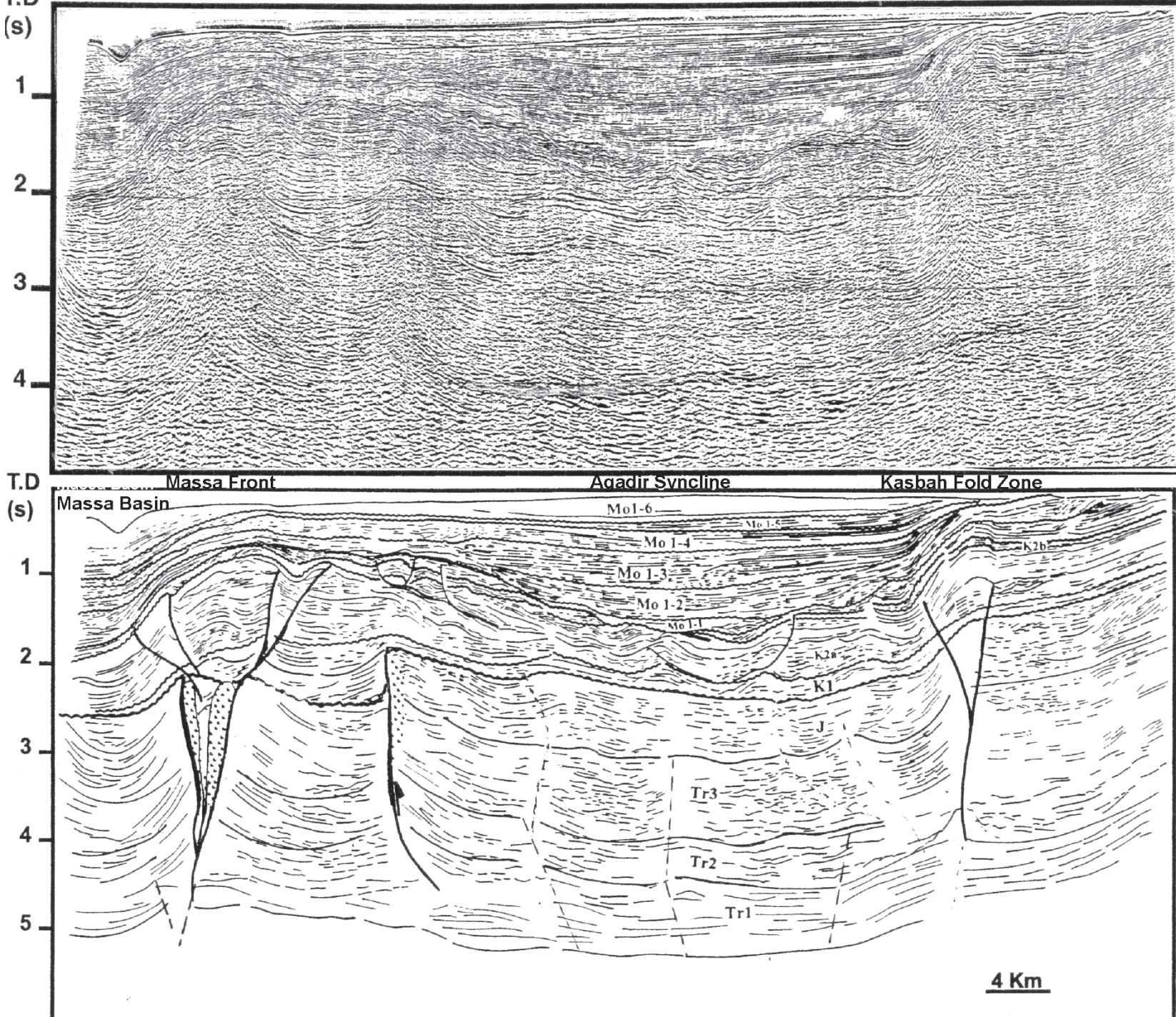

Fig. 2.-Seismic section (top) and interpretation (bottom) of the structures across the offshore Agadir area (after Mridekh, 2000). Tr, Triassic; J, Jurassic; K1, Early Cretaceous; K2a, Cenomanian and Turonian; K2b, Senonian; Mo1-1, Paleogene; Mo1-2, Lower Miocene; Mo1-3, Middle Miocene; Mo1-4, Late Miocene; Mo1-5 et Mo1-6, Plio-Quaternary.

based on the presence of Late Oligocene foraminifers, and older palynomorphs such as ${ }^{1}$ : Hystrichokolpoma cf. eisenackii Williams \& Downie, 1966, Homotryblium plectilum Drugg \& Loeblich Jr., 1967 (pre-Lower Oligocene) and Areoligera tauloma Eaton, 1976, Deflandrea phosphoritica Eisenack, 1938, and Isabelidinium pellucidum (Deflandre \& Cookson, 1955) Lentin \& Williams, 1977 (Eocene).
- Beneath a major unconformity, shales with intercalation of Upper Cenomanian (1,723-2,213 m) and Lower Cenomanian (2,213-2,603) limestones.

In borehole AGM-1, the encountered formations are, from top to base (fig. 3):

- Sands, silts and shales $(0-600 \mathrm{~m})$ of Miocene age (middle Miocene according to Mridekh, 2002).

- Unconsolidated shales and siltstones (600$650 \mathrm{~m})$ of Lutetian age.

1 Nomenclature of fossils corrected with respect to the original manuscript of Mridekh (2002). 
Souss-1

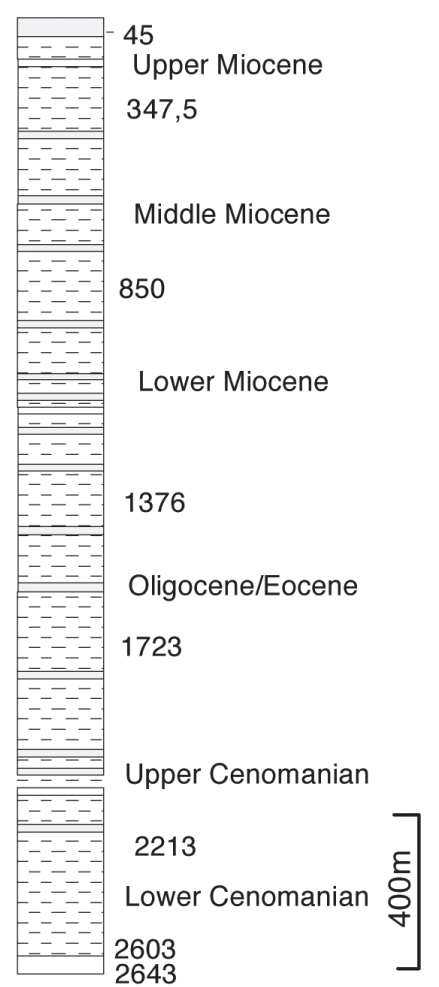

AGM-1
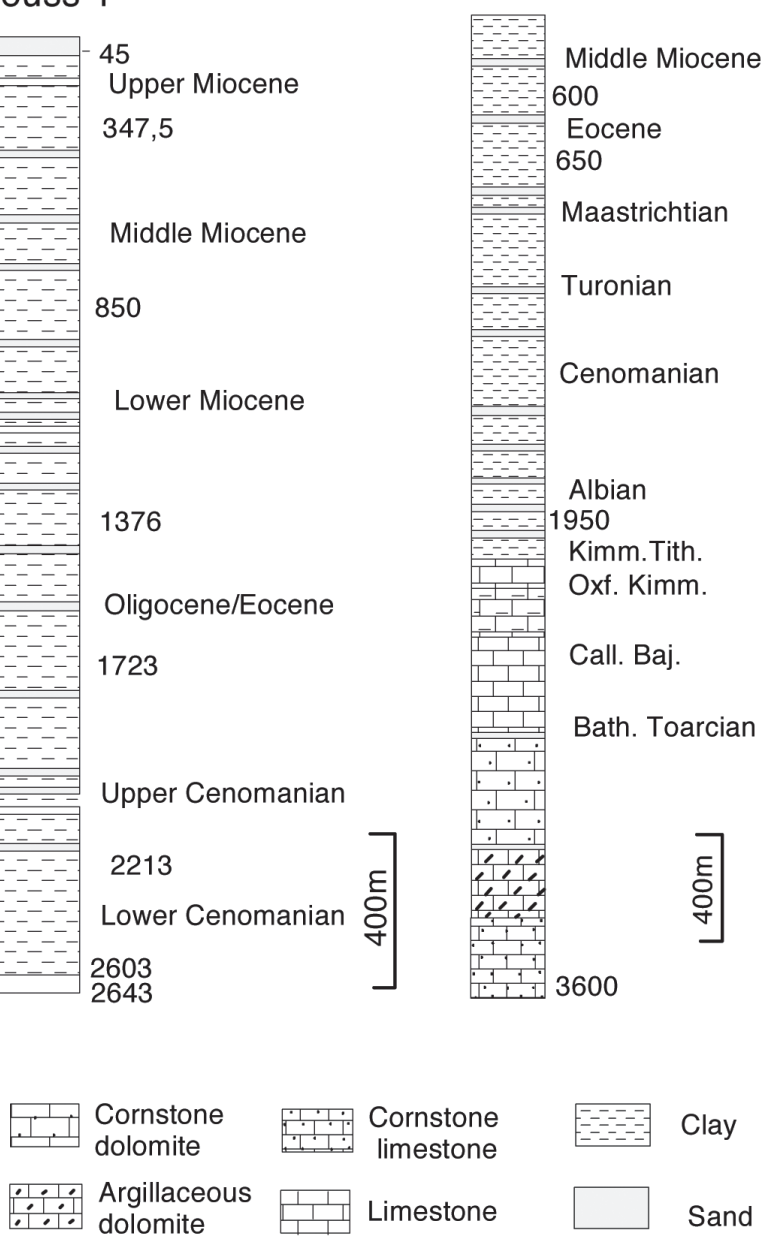

Fig. 3.-Lithology and age of recognized formations in boreholes Souss-1 and AGM-1, compiled from commercial reports in Mridekh (2000).

- Siltsones, grey to brown shales and shales intercalated with siltstones (650-1,950 m); this unit is dated as Albian at the base, and mainly covers the Cenomanian; the top is of Turonian to Maastrichtian age.

- Limestones of Toarcian to Tithonian age (1,950-3,600 m).

\section{Seismo- and tectono-stratigraphy}

For the purpose of our structural study, we distinguished two main units (fig. 4), designated in the following as Unit I and Unit II, separated by a major unconformity ( $D$ on fig. 4 ), which corresponds to the "Tertiary unconformity" of Samaka (2001).

Unit I consists of a set of high-amplitude reflectors, parallel to each other in most of the section

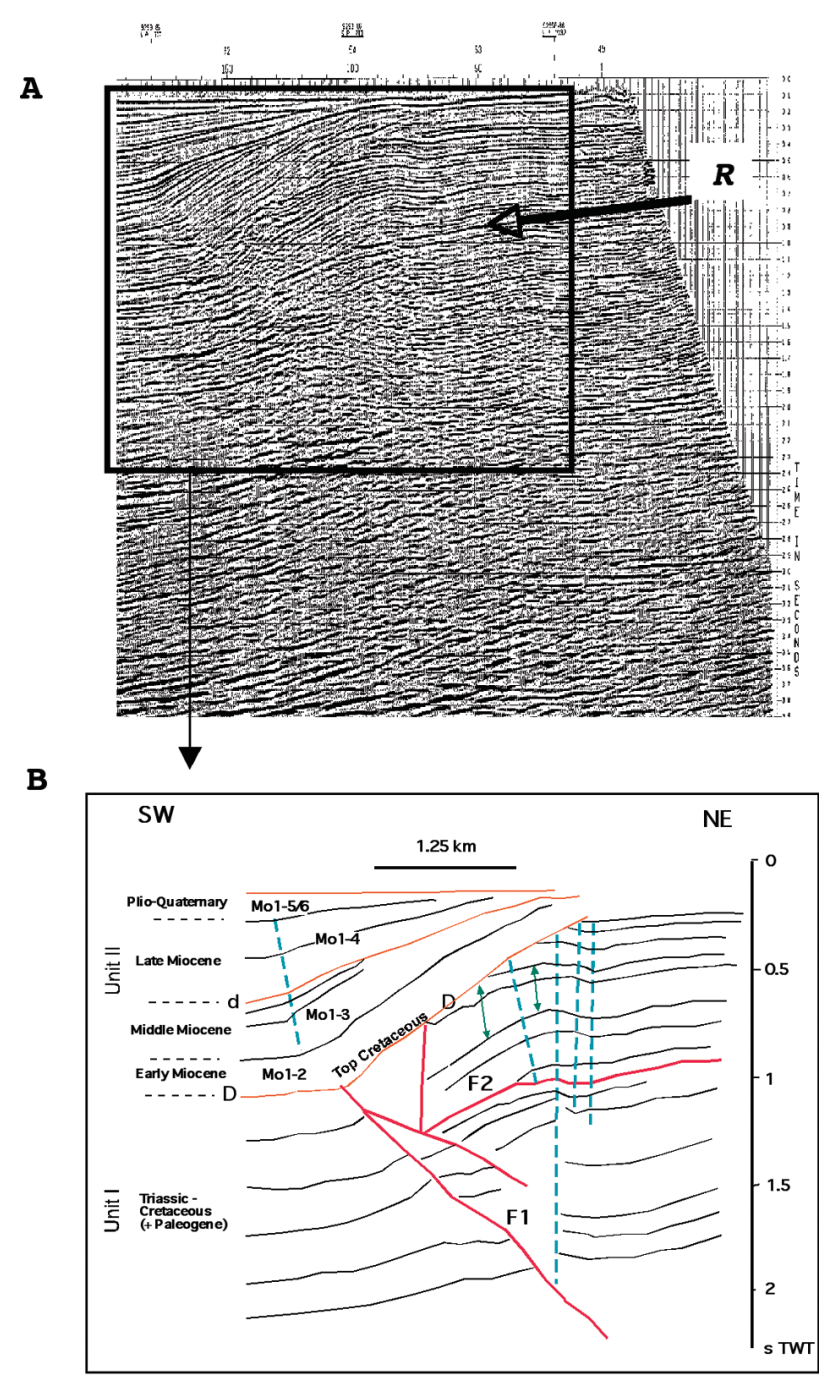

Fig. 4.-A) Detail of the north-easternmost part of profile A. B) Interpretation (see text for the nomenclature of units).

except at the top, where lenticular-shaped structures may reflect large channels filled with deposits. Correlation to borehole data shows that Unit I corresponds to the Triassic, Jurassic, Cretaceous and Paleogene strata, particularly to seismic units $\mathrm{Tr}$ to Mo1-1 in the terminology of Mridekh et al. (2000) and $\mathrm{Tr}$ to Pg of Hafid et al. (2006)). In this unit, it is possible to observe regional-scale seismic horizons (Mridekh et al., 2000; Samaka, 2001; Mridekh, 2002), emphasized by strong reflectors, as those of the tops of the Triassic, the Jurassic, the Albian and the Cenomanian units (fig. 2). The uppermost levels of Unit I are eroded and truncated by the major angular unconformity $D$ (fig. 2), against which they terminate in a toplap pattern. 


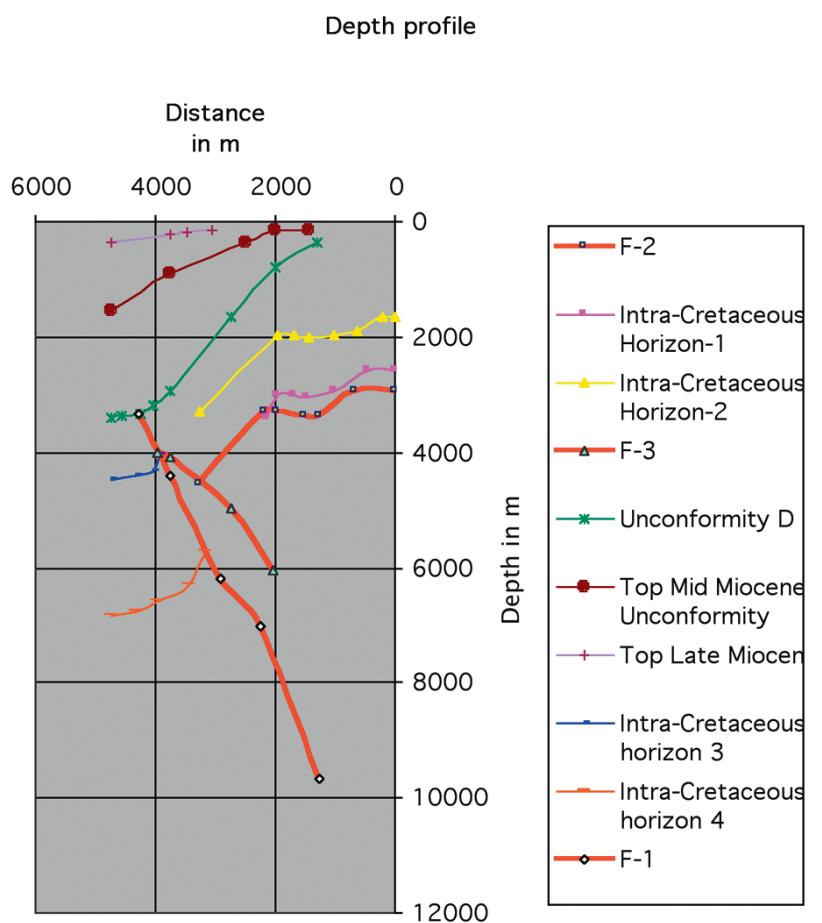

Fig. 5.-Depth section across profile A, showing the most conspicuous surfaces.

Above unconformity $D$, Unit II (fig. 4B) displays reflectors which are weaker than those of Unit I. The reflectors are more or less horizontal along the seismic section, except at the proximity of the KFZ near the onshore part, where they are arranged into fans that are open to the SW (fig. 4A). Tying to boreholes allowed us to correlate Unit II with units Mo1-2 to Mo1-6 of Mridekh et al. (2000) and Ng of Hafid et al. (2006). In detail, and according to the nomenclature of Mridekh (2002), 4 sub-units can be distinguished; they correspond to Mo1-2 (Early Miocene), Mo1-3 (Middle Miocene), Mo1-4 (Late Miocene) and Mo1-5 to Mo1-6 (Pliocene and Quaternary). Mo1-4 and Mo1-5 are separated by the minor unconformity $d$ (fig. 4).

\section{Structure}

In the north-easternmost segment of the studied profile (fig. 2), the previous studies have interpreted the steeply-dipping frontal fold or monocline as a flower structure (Mridekh et al., 2000; Mridekh, 2002; Hafid et al., 2006). However, detailed interpretation (fig. 4B) supported by a depth section (fig. 5) reveals that the major fault plane (F1) has an apparent dip to the NE, the value of which from the depth section is $60^{\circ}$, with a short step between 6,000 and $7,000 \mathrm{~m}$. We also interpreted a branch dipping about $50^{\circ} \mathrm{NE}$, merging upwards with the main plane at ca. $4,000 \mathrm{~m}$.

Within Unit I, this fault separates two blocks with a different structural pattern:

- In the footwall, the structure is rather simple with sub-horizontal reflectors, except at the proximity of fault plane F1, where they are tilted to the SW.

- The hanging wall shows a boxfold-like anticline above a strong reflector $(R)$ with a sinuous trace that can be interpreted as a flat and ramp fault surface (F2 in fig. 4B). In the northeastern limb, reflectors above $R$ are sub-parallel, whereas in the southwestern limb, they terminate against $R$ with downlaps, suggesting thickening of strata towards fault F1 in the SW (fig. 4A, B). The fold also shows two couples of axial surfaces that delimit kink bands (fig. 4B, dashed lines).

Unit II, which is nearly horizontal in the southwest of the profile in fig. $4 \mathrm{~B}$, has a SW dip in its northeastern part. This change in dip occurs after crossing a synclinal axial surface dipping to the NE (fig. 4B). The strata are arranged in a fan-like geometry above the south-western limb of the anticline, with an apex oriented to the NE. The higher part of the limb suggests a discrete axial surface located upon the eroded hinge of the underlying fold in Unit I.

In detail, the fan geometry in Unit II is different within the kink band of the limb between both axial surfaces: in sub-unit Mo1-3, the reflectors remain parallel to each other and terminate in toplaps against $d$; above the latter, the reflectors are rather uniformly convergent towards the anticline axial surface.

\section{Interpretation, implications and discussion}

\section{Kinematics of structures}

From the geometrical and kinematic point of view, several models can be investigated to find a kinematic pathway that could account for the observed structure: fault-propagation and fault-bend folding (Suppe et al., 1997), trishear folding (Erslev, 1991), displacement-gradient folding (Wickham 1995), etc.

Detailed observation of the growth fan leads to the following remarks:

- In sub-units Mo1-2 and Mo1-4, dips of the reflectors and thickness of the sets decrease toward 
the hinge; the converging fan along the fold limb suggests deformation by limb rotation, probably through displacement-gradient folding.

- In sub-unit Mo1-3, reflectors are parallel, with a constant dip, end in toplaps against unconformity $d$, and thin out above the anticline hinge, suggesting deformation by kink-band migration related to a fault-propagation or fault-bend folding.

From these two observations, it appears that the kinematic history of the KFZ is variable, resembling in many details to other reported cases, such as those of the Sant Llorenç de Morunis anticline in Spain (Suppe et al., 1997), the Lost Hills structure (Wickham, 1995; his fig. 7) and especially the Santa Fe Springs segment of the Puente Hills blind thrust near Los Angeles (fig. 3 in Shaw et al., 2002). However, retracing the detailed kinematic history is beyond the scope of the present paper since it needs a profile of much better quality and data.

\section{Chronology of deformation}

Although the uplift of the High Atlas chain started in latest Cretaceous times (Laville et al., 1977; Monbaron, 1982; Froitzheim, 1984), the paroxysmal phase is generally of Late Miocene - Pliocene age, as can be inferred from the deposition of thick conglomeratic formations at the chain borders (e.g. Petit et al., 1985; Fraissinet et al., 1988; Zouine, 1993; Chellaï \& Perriaux, 1996; Morel et al., 2000; Aït Hssaine, 2000). With respect to the data collected from continental (Allard et al., 1958; Ambroggi, 1963; Cahuzac, 1989), and marine (Mridekh et al., 2000; Samaka, 2001; Mridekh, 2002) areas, analysis of the northeastern segment of the studied profile leads to subdivide the geological history of the fault zone into three major stages, two of which are major events.

1. The increase in thickness of the Cretaceous beds in the southwestern limb of the anticline in the hanging wall does not seem to be related to halokinesis, which should have led to the development of a symmetric fan in the other limb. This suggests that either F1 was a syndepositional normal fault during the Cretaceous, or that the onset of anticline growth was during the Late Cretaceous, with a fan above the frontal part of the fold. Although there are indications for the onset of compression at that time in the distal part of the offshore basin (Hafid, 1999; Mridekh, 2002), it appears more logical to relate the fan to a syndepositional normal motion on fault $\mathrm{F} 1$, because of the absence of a clear fold.
2. By the Latest Cretaceous to Palaeogene, displacement along plane $\mathrm{F} 2$ led to the development of a fault-bend fold and subsequent erosion of its hinge (fig. 4). The lack of any comparable feature in the footwall of F1 suggests that displacement on fault F2 was transferred to plane F1. Consequently, in the limit of the datings provided by ONAREP / ONHYM, the first phase of compressional deformation in the area is of latest Cretaceous - Palaeocene age. However, some ambiguity remains on its exact age, as the onshore data indicate that, along the southern side of the western High Atlas, the Cretaceous formations are conformably overlain by the marine Conglomérat blanc, dated as Late Oligocene by Allard et al. (1958), and reassigned to the Early Miocene (Aquitanian / Burdigalian) by Cahuzac (1987), on the basis of paleontological and eustatic arguments.

On a regional scale, the offshore area is located in the continuation of the southwestern closure of the Ait Lamine anticline (fig. 1), which is kinematically a fault-bend fold (Mustaphi, 1997). According to analysis of offshore data, the development of this fold should be of Latest Cretaceous age, which is in accordance with data from the northern border of the Atlas (Froitzheim, 1984).

3. Afterwards, during the Early Miocene, reverse displacement on fault plane F1 deformed and tilted plane F2, and accentuated the fold structure, as attested by the continuation of fault plane F1 by the synclinal axial surface. The relatively large thickness of the Neogene strata implies that the rate of deposition was higher than that of anticlinal growth. This compressional regime was constant since the Early Miocene, and emphasized by the sedimentary fan within units Mo1-3 and Mo1-4. Inland, two major events are recorded by the undifferentiated Mio-Pliocene and Plio-Villafranchian foreland deposits; these two formations are separated by an unconformity reflecting a period of quiescence.

\section{Growth rate}

Measurement of the mean anticline growth can be inferred from the depth difference of selected reflectors of the growth fan (Table 1A). The mean vertical rate is $0.128 \mathrm{~mm} / \mathrm{y}$ for the whole Unit II, considering an Early Miocene age (23 Ma) for its base. This rate remained steady in the Middle Miocene $(0.124 \mathrm{~mm} / \mathrm{y})$, but seems to have slowed down since the Late Miocene, falling to $0.04 \mathrm{~mm} / \mathrm{y}$ (Table 1A). 
Table 1A.-Mean vertical growth calculated from main interpreted surfaces

\begin{tabular}{lccccc}
\hline & \multicolumn{2}{c}{ Depth of level $(\mathrm{m})$} & & Mean vertical growth \\
\cline { 2 - 4 } Surface & $\mathrm{SW}$ & $\mathrm{NE}$ & & Age Base (Ma) & 0.128 \\
\hline$D$ (Base Early Miocene) & 3,323 & 360 & 23 & 0.124 \\
\hline$d$ (Top Middle Miocene) & 1,528 & 160 & 11 & 0.040 \\
\hline Top Late Miocene to Present & 376 & 160 & 5.3 & 0 \\
\hline
\end{tabular}

Table 1B.--Individual layer mean vertical growth calculated from main units

\begin{tabular}{|c|c|c|c|c|c|}
\hline \multirow[b]{2}{*}{ Units } & \multicolumn{2}{|c|}{ Thickness of unit } & \multirow[b]{2}{*}{ Age base (Ma) } & \multirow[b]{2}{*}{ Age top (Ma) } & \multirow{2}{*}{$\begin{array}{l}\text { Mean vertical growth } \\
\text { rate }\left(\mathrm{mm} \cdot \mathrm{y}^{-1}\right)\end{array}$} \\
\hline & SW & $\mathrm{NE}$ & & & \\
\hline Pliocene-Present (Mo1-5) & 376 & 160 & 5.3 & 0 & 0.040 \\
\hline Late Miocene (Mo1-4) & $1152(1528-376)$ & 0 & 11 & 5.3 & 0.200 \\
\hline $\begin{array}{l}\text { Mo1-2 + Mo1-3 } \\
\text { (Early-Middle Miocene) }\end{array}$ & $1795(3323-1528)$ & $200(360-160)$ & 23 & 11 & 0.133 \\
\hline
\end{tabular}

Considering individual units (Table 1A) by levelling the top surfaces upon the two fault blocks, the rates are $0.133 \mathrm{~mm} / \mathrm{y}$ for Mo1-2 + Mo1-3, under $d, 0.2 \mathrm{~mm} / \mathrm{y}$ for Mo 1-4, and only $0.04 \mathrm{~mm} / \mathrm{y}$ above the latter.

The mean rate is comprised within the boundary values of $0.1-0.2 \mathrm{~mm} / \mathrm{y}$ uplift rate in the last 2-2.5 Myr calculated for the Kasbah anticline by Meghraoui et al. (1998), but is much lower than the slip rate calculated by Sébrier et al. (2006) for the Ameskroud fault $(0.4 \mathrm{~mm} / \mathrm{y}$ during the last 35 kyr $)$ and Tagragra anticline $(0.3 \mathrm{~mm} / \mathrm{y}$ for the last 2-2.5 Myr). These differences are not surprising because of the uncertainties on ages and tie points between wells and seismic sections, and the use of different parameters (uplift, slip rate) by different authors. In addition, we have used a much larger time span, probably with several episodes of fault quiescence.

Whatever the type of calculation, it clearly appears that the main growth stage with the higher slip rates occurred during the Late Miocene, which is in accordance with the episode of deposition of Mio-Pliocene conglomerates known inland.

\section{Implications on the seismic hazard in the Agadir area}

The study of the KFZ structure also allowed us to reassess the seismic hazard in the Agadir area, on the base of a comparison to similar seismogenic structures described from Los Angeles area (Shaw \& Suppe, 1996; Shaw et al., 2002).

The review of available data on seismicity (Cherkaoui, 1988; and online catalogue of earthquakes available at the CNR website http://sismolag.cnrst.ma/) and on focal mechanisms (Medina \& Cherkaoui, 1991; El Alami et al., 1992; Medina, 1994, 2008) shows that the events are few (Medina, 1994). For the period 1960-2007, only 20 events were inventoried in the Agadir area between $9.5^{\circ}-$ $10.05^{\circ} \mathrm{W} ; 30.25^{\circ}-30.7^{\circ} \mathrm{N}$ (Table 2). The list does not take into account the numerous aftershocks of the 1960 earthquake, since the epicentres of the events before 1992 are generally poorly constrained because of the low number of seismological stations in Morocco at that time. The largest shocks are those of February, 29 ${ }^{\text {th }}, 1960\left(I_{\mathrm{MSK}}=X ; \mathrm{M}=6\right)$, which destroyed the former city, and the events of April, $5^{\text {th }}, 1992(\mathrm{M}=4.7)$, and November, $16^{\text {th }} 2003$ $(M=4.2)$, which were felt by the local population.

Seven epicentres, among which those of the April, $5^{\text {th }}, 1992$ event and its aftershocks, are located immediately north of KFZ trace (fig. 1), strongly suggesting a possible relationship with the fault zone. This is supported by the shallow depth of the foci, in the range of $2 \mathrm{~km}$ only. For the other shocks, the depths of foci are not available (Table 2). Other epicentres are located close to fault systems and diapir walls as shown in figure 1.

Three focal mechanism solutions are available for these events, one of which is composite. The 
Table 2.-Epicentres of earthquakes in the bay of Agadir in the region $9.5^{\circ}-10.05^{\circ} \mathrm{W} ; 30.25^{\circ}-30.7^{\circ} \mathrm{N}$ for the period 1960-2007

\begin{tabular}{|c|c|c|c|c|c|c|c|}
\hline $\mathrm{N}^{\circ}$ & Date & Time & Latitude N & Long. W & $\mathrm{Z}$ & $\mathrm{M}(\mathrm{I})$ & Ref. \\
\hline 1 & $29-02-1960$ & $23-40-14$ & 30.45 & 9.62 & 1.4 & 5.9 & $\mathrm{CH} 88$ \\
\hline 2 & $12-09-1962$ & $21-07-08$ & 30.40 & 9.60 & $\mathrm{n}$ & IV & CH88 \\
\hline 3 & 16-09-1964 & 23-29-** & 30.40 & 9.60 & $\mathrm{n}$ & III & $\mathrm{CH} 88$ \\
\hline 4 & $11-05-1967$ & 20-14-06 & 30.50 & 9.50 & $\mathrm{n}$ & 2.7 & $\mathrm{CH} 88$ \\
\hline 5 & $31-03-1976$ & $17-30-* *$ & 30.60 & 9.39 & $\mathrm{n}$ & IV & $\mathrm{CH} 88$ \\
\hline 6 & 08-10-1976 & $21-29-06$ & 30.25 & 9.47 & 10 & 3.7 & $\mathrm{CH} 88$ \\
\hline 7 & 05-04-1992 & $21-16-38$ & 30.41 & 9.74 & 0.2 & 4.7 & EA92 \\
\hline 8 & 05-04-1992 & $21-50-57$ & 30.44 & 9.74 & 0 & 3.7 & EA92 \\
\hline 9 & 07-04-1992 & $13-35-24$ & 30.41 & 9.74 & 2.0 & 3.5 & EA92 \\
\hline 10 & 12-04-1992 & $11-19-40$ & 30.48 & 10.05 & 0.2 & $\mathrm{n}$ & EA92 \\
\hline 11 & 13-04-1992 & $22-41-35$ & 30.46 & 9.68 & 10.2 & $\mathrm{n}$ & EA92 \\
\hline 12 & 14-04-1992 & $20-44-46$ & 30.42 & 9.68 & 15.5 & $\mathrm{n}$ & EA92 \\
\hline 13 & 29-06-1997 & $17-21-43$ & 30.41 & 9.96 & $\mathrm{n}$ & 2.2 & CNR \\
\hline 14 & 06-07-1999 & $21-15-54$ & 30.27 & 9.90 & $\mathrm{n}$ & 2.7 & CNR \\
\hline 15 & 12-11-1999 & $20-41-50$ & 30.38 & 9.88 & $\mathrm{n}$ & 2.8 & CNR \\
\hline 16 & $16-11-2003$ & $13-08-16$ & 30.08 & 9.81 & $\mathrm{n}$ & 4.2 & CNR \\
\hline 17 & 29-01-2007 & $04-51-18$ & 30.47 & 9.73 & $\mathrm{n}$ & 3.6 & CNR \\
\hline 18 & 21-02-2007 & $13-24-47$ & 30.25 & 9.66 & $\mathrm{n}$ & 3.7 & CNR \\
\hline 19 & 03-06-2007 & $11-01-34$ & 30.25 & 9.79 & $\mathrm{n}$ & 3.2 & CNR \\
\hline 20 & $29-12-2007$ & $03-10-43$ & 30.41 & 9.67 & $\mathrm{n}$ & 3.5 & CNR \\
\hline
\end{tabular}

References: CH88 = Cherkaoui (1988); EA92 = El Alami et al. (1992); CNR = Online catalogue of the Centre National de la Recherche, Rabat (http://sismo-lag.cnrst.ma/). Aftershocks of the 1960 earthquake were omitted.

solutions for the February, 29th, 1960 event are very different from one author to another, ranging from reverse motion (Wickens \& Hodgson, 1967 in Udias et al., 1989), to strike-slip faulting with a N-S trending $P$ axis (Girardin et al., 1977), or E-W trending $P$ axis (e.g. Medina \& Cherkaoui, 1991). Because of the low quality of recordings and the poor azimutal distribution of the seismological stations at that date (Stevens \& Hodgson, 1968), it is difficult to reach a reliable solution for this event, without digitizing and modelling available records.

The focal mechanism solution for the main shock of April, $5^{\text {th }} 1992$ is thrust faulting along planes oriented N250; $53^{\circ}$ (with a sinistral component) and $\mathrm{N} 141 ; 70^{\circ}$ (with a dextral component). The composite solution constructed for the weak aftershocks (El Alami et al., 1992), is also an almost-pure thrust fault with both planes oriented $\mathrm{E}-\mathrm{W}\left(\mathrm{N} 83 ; 53^{\circ}\right.$ and N296; 42 ${ }^{\circ}$ ).

The magnitude of any earthquake that should occur along the KFZ fault can be evaluated with the help of the seismic moment equation (e.g. Frohlisch \& Apperson, 1992):

$$
\mathrm{M}_{\mathrm{o}}=\mu A s
$$

where $A$ is the area of the fault, $s$ the amount of displacement along the fault (in $\mathrm{cm}$ ) and $\mu$ is Young's modulus (taken to be $5.10^{11}$ dyn. $\mathrm{cm}^{-2}$ ).
The moment magnitude $\mathrm{M}_{\mathrm{w}}$ can be expressed by the equation of Hanks \& Kanamori (1979):

$$
\mathrm{M}_{\mathrm{w}}=2 / 3 \log \mathrm{M}_{\mathrm{o}}-10.7
$$

There are also several empirical equations and graphs set by Wells and Coppersmith (1994; their tables 2A-C), which express the relationships between the fault parameters. However, as we have two unknowns, the magnitude and the amount of displacement, we just use Hanks and Kanamori's equation to assess the maximum magnitude for a given mean displacement along the fault knowing the theoretical rupture area.

The size of the fault (at least $20 \mathrm{~km}$ length $\mathrm{x} 6 \mathrm{~km}$ width $=120 \mathrm{~km}^{2}$ ) suggests that, for a mean displacement of about $1 \mathrm{~m}$, earthquakes of magnitude $\mathrm{M}_{\mathrm{w}}=6.33$ are likely to occur, as in the case of the 1960 Agadir earthquake.

These data suggest that the KFZ is a potential seismogenic structure that should be taken into account in studies on seismic hazard, as for the Tildi (onshore and offshore segments), Lahouar, El Klea and south-Tagragra faults (Sébrier et al., 2006). However, it appears that larger earthquakes are not likely to occur, because of the highly segmented character of faults in the western part of the High Atlas Front, contrary to other well known structures, such as the San Andreas, Zagros or Taurus faults. 


\section{Regional extent of the South Atlas Front}

The structural pattern in the Agadir bay implies that the front of the High Atlas is offset to the southwest by the Tildi marine fault. This is a current feature in the southern border of the western High Atlas, where several structures are offset by transfer strike-slip faults (see above).

Concerning the continuation of the Atlas toward the Atlantic, the review of published papers indicates that the idea of a possible relationship between the South Atlas faults (or Tizi n'Test fault zone) and the Canary Islands was first exposed by Flament-Lieffrig (1979). Nairn et al. (1980) also suggested a connection through the "Tarfaya fault" because of the E-W trend of the Tarfaya margin. In contrast, other authors such as Schminke (1982), did not find from petrological data any clear genetic nor kinematic relationship between the two domains. Later, Weijermars (1987) suggested continuity between the "South Atlas Fault" and the eastern segment of the Hayes transform fault north of the Canary Islands; he considered this fault zone as the southern boundary of the Eurasian plate. However, the more recent work of Mustaphi et al. (1997, their figure 4) showed that the inverted El Kléa Triassic fault, the southernmost segment of the Atlas Front inland, rotates from NE-SW to NNE-SSW and runs parallel to the coast without reaching the Canary Islands. At a larger scale, Sahabi et al. (2004, their figure 6) also suggested continuity between the Atlas Front and the eastern boundary of the Tarfaya basin, at least during the Triassic. In the offshore Tarfaya basin, the recent studies of Abou Ali et al. $(2004,2005)$ only show NE-SW Mesozoic normal faults without any signs of inversion. Finally, the offshore/onshore studies of Hafid et al. $(2000,2006)$ suggest that, in the oceanic area, the High Atlas folds rotate and terminate in a mainly thin-skin, salt-driven, westward-thrusting pattern, which we interpret as an escape pattern.

At depth, it is noteworthy that there is a lithospheric thermal dome beneath the High and Middle Atlas and the Rif, that reaches the Agadir area to the west (Frizon de Lamotte et al., 2008). It would be very possible that this anomaly extends to the west and then to the Canary Islands; however, the problem cannot be assessed without a detailed geophysical study and especially by collecting geothermal data along the Tarfaya margin (A. Rimi, pers. comm.).

We conclude from the exposed data, that the Atlas front may terminate in a Rif/Betics-like pat- tern, i.e. as an arc within the Atlantic, with no shallow connection with the Canary Islands; however, at a lithospheric scale, both domains may be thermally connected, but this needs collecting thermal and gravimetric data along the Tarfaya segment.

\section{Conclusions}

1. Re-interpretation of the north-eastern segment of a profile realized across the Agadir bay along a NE-SW trend shows two tectono-stratigraphic sequences: Unit II, which displays a simple structure, laying unconformably on Unit I, with a complex structure dominated by a NE-dipping reverse fault (F1). Correlation with boreholes Souss-1 and AGM-1 allowed us to assign Unit I to the Triassic to Palaeogene and Unit II to the Miocene-Present.

2. The NE block shows a fault plane of the ramp-flat type (F2); and the overlying fold can be interpreted as a fault-bend fold, with a SW-vergence.

3. Three stages were distinguished: (1) during the Cretaceous, F1 could have been a syndepositional normal fault with the NE block moving downwards; (2) towards the end of the Cretaceous or by the Palaeogene, the displacement of plane F2 induced the development of a fault-bend fold and to erosion of the forelimb and hinge of the fold; displacement along F2 was transferred to fault F1; (3) afterwards, during the Miocene, the reverse motion of F1 deformed and tilted the plane F2 and accentuates the folded structure. This evolution is typical for a frontal basin above a fault propagation fold; growth of the anticline occurred mainly during Late Miocene times.

4. Seismic activity recorded in the Agadir bay appears to be clearly related to this fault zone, as also inferred from focal mechanisms. Seismic moment evaluation suggests that earthquakes of magnitude $\mathrm{M}_{\mathrm{w}}=6$ or more are likely to occur.

\section{ACKNOWLEDGEMENTS}

We would like to thank the Exploration Direction of ONHYM (ex-ONAREP), pole Hydrocarbons, for facilitating the seismic profiles. We also thank John S. Wickham (University of Texas at Arlington) for his remarks. Hamid Slimani (Institut Scientifique) kindly corrected the nomenclature of dynoflagellates. Michel Sébrier and Miguel Doblas reviews helped improving the first draft of the manuscript. This study was in part conducted within the activities of the team "Moroccan Meso-Cenozoic margins" at the Institut Scientifique, with partial funding from University Mohammed V - Agdal, Rabat. 


\section{References}

Abou Ali, N.; Chellai, E.H. \& Nahim, M. (2004). Anatomie d'une marge passive hybride. Marge Ifni/Tan-Tan au Mésozoïque. Apports des données géophysiques. Estudios Geologicos, 60: 111-121. doi:10.3989/egeol.04603-683

Abou Ali, N.; Hafid, M.; Chellai, E.H. \& Nahim, M. \& Zizi, M. (2005). Structure du socle, sismostratigraphie et héritage structural au cours du rifting au niveau de la marge Ifni/Tan-Tan (Maroc sud-occidental). Comptes Rendus Geoscience, 337: 1267-1276. doi:10.1016/j.crte.2005.07.003

Ait Hssaine, A. (2000). Evolution géomorphologique du piémont sud-atlasique dans la région de Taroudant (SW-Maroc) au cours du Tertiaire et du Pléistocène inférieur. Bulletin de l'Institut Scientifique, Rabat, 22 (1999-2000): 17-28.

Allard, P.L.; Coché, E. \& Duffaud, F. (1958). L'Oligocène dans le Haut Atlas occidental. Notes \& Mémoires du Service géologique du Maroc, 16: 7-16.

Alonso-Gavilán, G.; González-Delgado, J.A.; Civis, J.; Pais, J. \& Legoinha, P. (2001). El Neógeno superior del Valle del Souss (Agadir, Sur de Marruecos). Geogaceta, 29: 7-10.

Ambroggi, R. (1963). Etude géologique du versant méridional du Haut Atlas occidental et de la plaine du Souss. Notes \& Mémoires du Service géologique du Maroc, 157: 1-322.

Cahuzac, B. (1989). Sur le Tertiaire marin de la région d'Agadir. ler Colloque sur le Néogène atlantoméditerranéen, Tétouan, 12-14 mai 1989, 93-94.

Chellai, E.H. \& Perriaux, J. (1996). Evolution géodynamique d'un bassin d'avant-pays du domaine atlasique (Maroc): exemple des dépôts néogènes et quaternaires du versant septentrional de l'Atlas de Marrakech. Comptes Rendus de l'Académie des Sciences de Paris, 322, IIa: 727-734.

Cherkaoui, T.-E. (1988). Fichier des séismes du Maroc et des régions limitrophes 1901-1984. Travaux de l' Institut Scientifique, Rabat, série Géologie \& Géographie physique, 17, $158 \mathrm{pp}$.

Cherkaoui, T.-E.; Medina, F. \& Hatzfeld, D. (1991). The Agadir earthquake of February 29, 1960. Examination of some of the parameters. In "Seismicity, seismotectonics and seismic risk of the ibero-maghrebian region". Instituto Geografico Nacional, Madrid, Monografia nº 8, 133-148.

Duffaud, F. (1962). Le cadre géologique de la région d'Agadir. Notes \& Mémoires du Service géologique du Maroc, 154: 5-6.

Duffaud, F. (1981). Carte géologique du Maroc au 1/100 000, feuille Imi n'Tanout. Notes \& Mémoires du Service géologique du Maroc, 203.

El Alami, S.O.; Medina, F. \& Jebli, H. (1992). Etude du séisme d'Agadir du 5 avril 1992. Gaia, Lisboa, 5: 1-5.

El Maamar, K. (1988). Etude tectonique et microtectonique dans la bordure sud du Haut Atlas occidental (région d'Agadir - Maroc). Thèse de 3ème cycle, Univ. Montpellier, France, 97 pp.
Erslev, E.A. (1991). Trishear fault-propagation folding. Geology, 19: 617-620.

doi:10.1130/0091-7613(1991)019<0617:TFPF >2.3.CO;2

Flament-Lieffrig, D. (1979): La marge continentale africaine du Sud des Iles Canaries au détroit de Gibraltar. Géologie des bassins El Aiun-TarfayaEssaouira. Leur évolution dans la contexte atlantique. Thèse de 3e cycle, Paris VI, 147 pp.

Fraissinet, C.; Zouine, M.; Morel, J.-L.; Poisson, A.; Andrieux, J. \& Faure-Muret, A. (1988). Structural evolution of the southern and northern Central High Atlas in Paleogene and Mio-Pliocene times. In: The Atlas system in Morocco. Jacobshagen V.H. (ed.). Springer-Verlag, series Lecture Notes in Geosciences, 15: 275-291.

Frizon de Lamotte, D.; Zizi, M.; Missenard, Y.; Hafid, M.; El Azzouzi, M.; Maury, R.C.; Charrière, A.; Taki, Z.; Benammi, M. \& Michard, A. (2008). The Atlas System. In: Continental evolution: the geology of Morocco (Michard, A.; Saddiqi, O.; Chalouan, A. \& Frizon de Lamotte, D., eds) Springer-Verlag, BerlinHeidelberg, series Lecture Notes in Earth Sciences, 116, 133-202.

Froitzheim, N. (1984). Oberkretazische Vertikaltektonik im Hohen Atlas SW' von Marrakech/MarokkoRekonstruktion eines Bewegungsablaufs im Frühstadium der Atlas-Orogenese. Neues Jahrbuch Geologie und Paläontologie Mh, 8: 463-471.

Girardin N., Hatzfeld D. \& Frogneux M. (1977). Etude de la sismicité dans la région de l'arc de Gibraltar et l'Algérie du Nord. Bulletin de la Societé Géologique de France, 19: 741-747.

Hafid, M.; Aït Salem, A. \& Bally A.W. (2000). The western termination of the Jbilet High Atlas system (Offshore Essaouira Basin, Morocco). Marine and Petroleum Geology, 17: 431-443. doi:10.1016/S0264-8172(98)00082-8

Hafid, M.; Zizi, M.; Bally, A.W. \& Aït Salem, A. (2006). Structural styles of the western onshore and offshore termination of the High Atlas, Morocco. Comptes Rendus Geoscience, 338: 50-64. doi:10.1016/j.crte.2005.10.007

Hanks, T.C. \& Kanamori, H. (1979). A moment magnitude scale. Journal of Geophysical Research, 84, B5: 2348-2350. doi:10.1029/JB084iB05p02348

Laville, E.; Lesage, J.-L. \& Séguret, M. (1977). Géométrie, cinématique (dynamique) de la tectonique atlasique sur le versant sud du Haut Atlas marocain. Aperçu sur les tectoniques hercyniennes et tardi-hercyniennes. Bulletin de la Société Géologique de France, 19: 527-539.

Mather, C. (1980). Agadir Maritime permit. Occidental Exploration and Production Company. Unpublished report ONHYM.

Medina, F. (1986). Étude structurale de la partie occidentale d'un accident bordier atlasique: l'accident d'Ichemrarene - Imi n'Tanout (Haut Atlas occidental). Implication sur la chronologie relative des phases compressives tertiaires. Bulletin des Sciences de la Terre, Rabat, 2: 86-98.

Medina, F. (1994). Evolution structurale du Haut Atlas occidental et des régions voisines du Trias à l'Actuel 
dans le cadre de l'ouverture de l'Atlantique central et de la collision Afrique-Europe. Thèse d'Etat, Université Mohammed V, Fac. Sci. Rabat, 1155, 260 pp.

Medina, F. (2008). Catalogue of focal mechanisms of Moroccan earthquakes for the period 1959-2007. Documents de l' Institut Scientifique, Rabat, 23, 46 pp.

Medina, F. \& Cherkaoui, T.-E. (1991). Focal mechanisms of the Atlas earthquakes, and tectonic implications. Geologische Rundschau, 80, 3: 639-648. doi:10.1007/BF01803691

Meghraoui, M., Outtani, F., Choukri, A.; Frizon de Lamotte, D. (1998). Coastal Tectonics across the South Atlas Thrust Front and the Agadir active zone, Morocco, in: Coastal Tectonics (Steward, J.H. \& Vita-Finzi C., eds.) Geological Society of London, Special Publication, 146, 239-253.

Monbaron, M. (1982). Précisions sur la chronologie de la tectogenèse atlasique: exemple du domaine atlasique mésogéen du Maroc. Comtes Rendus de l'Académie des Sciences de Paris, 294, sér. II: 883-886.

Morel, J-L.; Zouine, E-M.; Andrieux, J. \& Faure-Muret, A. (2000). Déformations néogènes et quaternaires de la bordure nord haut-atlasique (Maroc): rôle du socle et conséquences structurales. Journal of African Earth Sciences, 30: 119-131. doi:10.1016/S0899-5362(00)00011-7

Mridekh, A.; Toto, E.A.; Hafid, M. \& El Ouataoui, A. (2000). Structure sismique de la plate-forme Atlantique au large d'Agadir (Maroc sud-occidental). Comptes Rendus de l'Académie des Sciences de Paris., Sciences de la Terre et des Planètes, 331: 387-392.

Mridekh, A. (2002). Géodynamique des bassins mésocénozö̈ques de subsurface de l'offshore d'Agadir (Maroc sud-occidental): contribution à la reconnaissance de l' histoire atlasique d'un segment de la marge atlantique marocaine. Thèse de Doctorat, Université Ibn Tofaïl, Fac. Sci. Kénitra.

Mustaphi, H., (1997). Apport des données de subsurface (forage et profils sismiques) et de la modélisation à l'étude de l'évolution du bassin du Souss du Trias à l'actuel. Thèse de $3^{\text {ème }}$ Cycle, Université Mohammed V, Faculté des Sciences, Rabat, 284 pp.

Mustaphi, H.; Medina, F.; Jabour, H. \& Hoepffner, Ch. (1997). Le bassin du Souss (Haut Atlas occidental, Maroc): résultat d'une inversion tectonique contrôlée par un détachement profond. Jounal of African Earth Sciences 24: 153-168. doi:10.1016/S0899-5362(97)00033-X

Nairn, A.E.M.; Noltimier, H.C. \& Nairn, B. (1980). Surface magnetic survey of the Souss basin, southeastern Morocco: evaluation of the tectonic role postulated for the Agadir and Tarfaya fault zones and the South Atlas flexure. Tectonophysics, 64: 235-248. doi:10.1016/0040-1951(80)90099-2

Petit, J.P.; Raynaud, S. \& Coutru, J.P. (1985). Microtectonique cassante lors du plissement d'un conglomérat (Mio-Pliocène du Haut Atlas- Maroc). Bulletin de la Société géologique de France, (8), I, 3: 415-421.

Samaka, F. (2001). Bassin offshore d'Agadir. Unpublished Report, ONAREP.
Schminke, H.-U. (1982). Volcanic and chemical evolution of the Canary Islands. In: Geology of the Northwest African continental margin (Von Rad, U.; Hinz, K.; Sarnthein, M. \& Seibold, E., eds) Springer-Verlag, Berlin, 273-306.

Sebrier, M.; Siame, L.; Zouine, E.M.; Winter, T.; Missenard, Y. \& Leturmy, P. (2006). Active tectonics in the Moroccan High Atlas. Comptes Rendus Geosciences, 338: 65-79. doi:10.1016/j.crte.2005.12.001

Stevens, A.E. \& Hodgson, J.H. (1968). A study of $P$ nodal solutions (1922-1962) in the Wickens Hodgson catalogue. Bulletin of the Seismological Society of America, 58: 1071-1082.

Shaw, J.H. \& Suppe, J. (1996). Earthquake hazards of active blind-thrust faults under the central Los Angeles basin, California. Journal of Geophysical Research, 101, B4: 8623-8642. doi:10.1029/95JB03453

Shaw, J.H.; Plesch, A.; Dolan, D.F.; Pratt; T.L. \& Fiore, P. (2002). Puente Hills blind-thrust system, Los Angeles, California. Bulletin of the Seismological Socety of America, 92: 2946-2960. doi:10.1785/0120010291

Suppe, J. (1983). Geometry and kinematics of fault-bend folding. American Journal of Science, 283: 684-721.

Suppe, J. \& Medwedeff, D.A. (1990). Geometry and kinematics of fault-propagation folding. Eclogae Geologicae Helvetiae, 83: 409-454.

Suppe, J.; Sàbat, F.; Muñoz, J.A.; Poblet, J.; Roca, E. \& Vergés, J. (1997). Bed-by-bed growth by kink-band migration: Sant Llorenç de Morunys, Eastern Pyrenees. Journal of Structural Geology, 19, 3-4: 443-461.

Udías, A.; Buforn, E. \& Ruiz de Gauna, J. (1989). Catalogue of focal mechanisms of european earthquakes. Department of Geophysics, Universidad Complutense, Madrid, 274 pp.

Weijermars, R. (1987). A revision of the EurasianAfrican plate boundary in the western Mediterranean. Geologische Rundschau, 76: 667-676. doi:10.1007/BF01821057

Weisrock, A.L.E. (1980). Géomorphologie et paléoenvironnements de l'Atlas atlantique. Thèse Paris I, 931 pp., published in Notes \& Mémoires du Service géologique du Maroc, 332 (1993), 488 pp.

Wells, D.L. \& Coppersmith, K.J. (1994). New empirical relationships among magnitude, rupture length, rupture width, rupture area and surface displacement. Bulletin of the Seismological Society of America, 86: 974-1002.

Wickham, J. (1995). Fault displacement-gradient folds and the structure at Lost Hills, California (U.S.A.). Journal of Structural Geology, 17, 9: 1293-1302. doi:10.1016/0191-8141(95)00029-D

Zouine, E.M. (1993). Géodynamique récente du Haut Atlas. Evolution de sa bordure septentrionale et du Moyen Atlas sud-occidental au cours du Cénozoïque. Thèse d'Etat, Rabat, 308 pp.

Recibido el 21 de octubre de 2008 Aceptado el 2 de septiembre de 2009 Publicado online el 3 de diciembre de 2009 


\title{
ERRATUM
}

\section{Structure of the Kasbah fold zone (Agadir bay, Morocco). Implications on the chronology of the recent tectonics of the western High Atlas and on the seismic hazard of the Agadir area. [ Estudios Geológicos, 2009, 65(2) 121-132]}

\author{
A. Mridekh¹, F. Medina², N. Mhammdi², F. Samaka ${ }^{3}$, R. Bouatmani ${ }^{4}$
}

In the original publication, in page 129 , at the bottom of the left column, parameter $\mu$ was wrongly defined as Young's modulus in the formula:

$M_{0}=\mu A s$

In fact, it corresponds to the rigidity modulus defined by $(\mu=E / 2(1+v)) E$ being Young's modulus and $v$ being Poisson's Ratio.

However, the following calculations remain correct, as the used values correspond to those of the rigidity.

1 Université Moulay Ismail, Faculté des Sciences et Techniques, Département de Géologie, Errachidia, Morocco.

2 Université Mohammed V - Agdal, Institut Scientifique, Département des Sciences de la Terre, B.P. 703 Agdal, Rabat, Morocco. email: medina@ israbat.ac.ma

3 ONHYM, pole Hydrocarbures, Av. Al Fadila, CYM, Rabat. Present address: Institut privé La Réserve, Mehdia (Kenitra), Morocco.

4 GETECH Group plc, Elmete Hall, Elmet lane, Leeds LS8 2LJ, United Kingdom. 